\title{
O feminino e o masculino na dança: das origens do balé à contemporaneidade
}

\author{
Marília Del Ponte de Assis* \\ Maria do Carmo Saraiva**
}

\begin{abstract}
Resumo: O objetivo desse trabalho foi efetuar uma reflexão sobre as representações do feminino e do masculino na dança cênica ocidental, das origens do balé à contemporaneidade. Buscou-se compreender alguns momentos de transição quanto aos papéis sexuais, em disputas e reciprocidades apresentadas no palco e, por vezes, fora dele. O suporte teórico dos Estudos Culturais foi utilizado no estudo da dança, enquanto uma prática cultural, incluindo também como "textos" os corpos em movimento; isso possibilitou uma melhor compreensão da codificação de estilos de dança, que comunicam, expressam e transformam representações associadas ao feminino e ao masculino.
\end{abstract}

Palavras-chave: Dança. Representações de feminilidade e masculinidade. Estudos Culturais.

\section{INTRODUÇÃO}

Este trabalho trata do feminino e do masculino na dança cênica ocidental, buscando refletir sobre o que se convencionou chamar de "fragmentos historiográficos" das origens do balé à contemporaneidade. Para tanto, optou-se pela abordagem teórica dos Estudos Culturais, que constituindo um campo de estudos que articula várias disciplinas na abordagem de aspectos culturais da sociedade, podem ser entendidos como um empreendimento interdisciplinar, planejado para estudar, de forma mais ampla, as práticas culturais (ESCOSTEGUY, 2004; SCHULMAN, 2004). Essas práticas encontram-se numa lista que permanece aberta,

\footnotetext{
"Membro do Grupo de Estudos de Gênero e Dança (GEDA/UFSC), Universidade Federal de Santa Catarina, Florianópolis, SC, Brasil. E-mail: mdpassis@yahoo.com.br

"Professora do Programa de Pós-Graduação em Educação Física, Universidade Federal de Santa Catarina, Florianópolis, SC, Brasil. E-mail: marcarmo1952@gmail.com
} 
compreendendo, sobretudo, a cultura popular, as cerimônias e os rituais, os comportamentos cotidianos, nas mais diversas circunstâncias, e as artes dos espetáculos, encenadas em amplos contextos e localizações.

Os Estudos Culturais, assim como a Sociologia, tem sido negligentes em relação à dança, cuja análise vem sendo evitada em comparação a outras formas expressivas, faltando, nas perspectivas cultural, histórica e social, abordagens e discussões mais amplas entre os/as teóricos/as da dança, principalmente no direcionamento aos papéis sexuais (MCROBBIE, 1997). As artes, muitas vezes, tentam corroer esses rígidos papéis, e a dança, especificamente, oferece modelos de atitudes e comportamento de papel sexual, apresentando e conferindo poder a mensagens, simulações e revelações. Os papéis sexuais, construídos social e culturalmente, quando transformados em dança, veículo crítico de comunicação e expressão, podem enriquecer o discurso sobre o feminino e o masculino, o que foi proposto por Hanna (1999). Para esta autora, uma análise da dança nos palcos revela reciprocidades e disputas dos sexos, em imagens móveis de predominância de um ou outro papel sexual.

Segundo Siegel (1996), especialmente no final do século XX, os campos da história e da crítica da dança permaneceram parados, pois, mesmo sabendo-se que a dança muito tem contribuído para a vida cultural, o estudo destas contribuições tem sido rudimentar. Thomas (1996) compartilha dessa mesma ideia, citando que a Antropologia da dança tem alguns focos de interesse na "sistematização" de teorias acerca da estrutura e funções da dança. Novas tendências, então, buscam explicar as relações entre dança e cultura, analisando a dança como modo de representação.

Foi a partir do século XX que o conceito de cultura teve ligação maior com as artes como "obras ou práticas que representam e dão sustentação ao processo geral de desenvolvimento humano" (CEVASCO, 2004, p. 8). No entanto, no contexto inglês, os estudos de cultura eram como uma extensão dos estudos literários, pois a 
formação dos estudos culturais deu-se basicamente a partir de obras de pensadores que eram primordialmente críticos literários. É nesse sentido que Desmond (1997) cita que os estudos culturais continuam bastante baseados em textos ou objetos, com predomínio de textos literários, estudos de textos de filmes e objetos históricos de arte. $\mathrm{O}$ objeto central dos estudos culturais não é o texto, "mas a vida subjetiva das formas sociais em cada momento de sua circulação, incluindo corporificações textuais" (JOHNSON, 2004, p. 75) e muito se ganhará com a inclusão de pesquisas em dança e estudos do movimento humano nas questões relativas aos estudos culturais. Mesmo os trabalhos críticos sobre o corpo são concentrados mais em representações deste do que em suas ações/movimentos como um "texto" em si. Alargando-se os estudos de "textos" corporais para incluir a dança, em todas as suas manifestações, aumenta-se a compreensão de como identidades sociais são formadas através do movimento corporal e codificadas em estilos de dança.

Se estilos de dança são constituintes de relações sociais, rastrear a história destes estilos e seu alastramento de um grupo para outro, ou de uma área para outra, bem como as mudanças que ocorrem nessa transmissão, podem ajudar a desvendar as ideologias mutantes atreladas ao discurso corporal, como afirma Desmond (1997), bem como a análise das representações de gênero nas formas culturais. Essas não refletem apenas definições sociais de feminilidade e masculinidade, mas estão ativamente envolvidos nos processos através dos quais o gênero é construído (BURT, 1995). Assim, estudar o caminho da migração da dança, as representações de gênero nela, e as mudanças resultantes na sua significação são importantes eixos de análises.

Assim, os estudos culturais como um caminho teórico a ser trilhado nos trabalhos em dança e gênero podem ser úteis, bem como os estudos culturais se enriqueceriam com novas corporificações textuais, abarcando a arte da dança e outras práticas culturais em seus aspectos históricos, pedagógicos, técnicos e cênicos. 


\section{FRAGMENTOS HISTORIOGRÁFICOS: DO BALÉ À CONTEMPORANEIDADE}

Mais do que uma descrição linear da história da dança, e sem entrarmos na questão de comparação dos gêneros de dança , a interpretação a seguir trata de personagens e características que, de certa forma, "dividiram" internamente a dança, deixando marcas e fazendo história, revelando reciprocidades e disputas entre os sexos na dança cênica ocidental, do balé clássico à dança contemporânea.

Sabe-se que a dança ocidental, no período que data da Idade Média, séculos V a XV, até chegar aos palcos dos teatros, passou por um caminho que compreendeu basicamente os rituais religiosos, as encenações nas praças públicas, as festas populares e os salões da corte. A partir da Renascença do século XVI o balé começou a se delinear na Itália, tendo na França seu apogeu. Enquanto um movimento artístico e social, o Renascimento deu à dança grande desenvolvimento, sendo uma nova concepção de mundo que apresentava um pensamento mais crítico, especialmente nos planos artístico, cultural e filosófico, e assim, a influência de outras manifestações artísticas como a poesia, a literatura, a música e a pintura emolduraram o desenvolvimento do balé. As apresentações nessa época, ao mesmo tempo em que serviam de divertimento nas festas nos salões da elite, eram oportunidades em que se definiam as posições sociais, celebrando-se as relações de poder (GITELMAN, 1998), sendo a dança da corte uma "metáfora das relações políticas e sociais de uma trama bem ajustada de hierarquias" (PEREIRA, 2006, p. 175), que se estendeu pelos séculos XVI e XVII, passando do religioso ao político o cunho da dança.

Nesse período dançavam apenas os homens, que ainda não tinham formação específica nem virtuosismo técnico, e que começaram a se travestir para os papéis femininos; durante as principais apresentações, mulheres eram apenas plateia. A dança era, então, muito além de entretenimento: as apresentações na corte tinham como objetivo a socialização e inclusão de homens num grupo, fazendo parte da educação dos jovens da elite que ambicionavam aumentar o seu prestígio, e uma das formas de conseguir isto consistia 
em encorajar as artes e a cultura. Somente após esses grandes espetáculos e interação entre os homens é que se iniciavam outros tipos de bailes, nos quais intérpretes e público se reuniam e mulheres podiam participar (AU, 2002; ANDERSON, 1978).

Estudos indicam que foi depois da era do Rei Luís XIV de Bourbon (1638-1715) que a cultura ocidental passou a associar o homem que dança profissionalmente com a homossexualidade e efeminação. Talvez isso se deva ao fato de que ele levou o balé das cortes para os palcos dos teatros, exigindo mais do que uma dança social. Com isso, já no século XVII, o balé se tornara refinado, sendo executado por bailarinos profissionais e não mais os homens da nobreza. A inclusão de bailarinas só se deu em 1681, com Mademoiselle Lafontaine (1655-1738), tornando-se o balé profissional uma arte para ambos os sexos (SIQUEIRA, 2006; ANDERSON, 1978).

No século XVIII, a Ópera de Paris era um dos centros mundiais da dança, onde as bailarinas começaram a se destacar, ocupando os principais lugares nos espetáculos, aperfeiçoando esta arte que até então era concebida de acordo com o corpo masculino (SIQUEIRA, 2006). Um desprestígio na dança foi causado pelas revoluções francesa e industrial (séculos XVIII e XIX), período relacionado ao pecado, frouxidão moral e inimigo da vida espiritual; e o corpo, até então instrumento de prazer, passou a ser um instrumento de produção. Por isso e pela baixa remuneração da profissão, a dança não era atrativa para os homens, que renunciaram à profissão, passando as mulheres a ter mais oportunidades de apresentação. No entanto, a questão da prostituição era latente, e as "garotas de balé" tinham uma conotação negativa até meados do século XX. Bailarinas eram uma fonte de excitação, e por vezes, satisfação sexual. A simples exibição de pernas no balé atraía a atenção de homens ricos, que se apaixonavam pelas belas bailarinas e suplicavam recompensas mais íntimas, e assim, muitas bailarinas com menos destaque deixavam os palcos para se tornarem prostitutas (HANNA, 1999). 
Anderson (1978) cita que, nesse período, os/as bailarinos/as eram olhados/as com ambivalência moral. A Igreja condenava o teatro e não fazia o funeral ou casamento de um/a ator/atriz ou bailarino/a, mas bispos e cardeais contratavam bailarinos/as para diversão em seus banquetes, e inclusive, algumas bailarinas eram suas amantes.

Todavia, a evolução técnica do balé, no mesmo período, traz destaques para o papel das bailarinas na sociedade. Por exemplo, Marie Sallé (1707-1756), que manteve para o público uma imagem de pureza, apesar das desconfianças de que seria lésbica, foi uma das primeiras a abolir os incômodos trajes da época, como as perucas e sapatos altos. Marie Camargo (1710-1770) encurtou as saias e foi uma das primeiras bailarinas a dançar como homem e alcançar brilhantismo técnico, até então reservado aos bailarinos (ANDERSON, 1978). Pereira (2006) conta que esses centímetros a menos no comprimento das saias foram motivo de grande alvoroço, e também, de uma popularidade maior da bailarina. Mas a hipocrisia da classe que financiava alguns teatros obrigou as bailarinas da Ópera a descer o comprimento das saias, para não inflamar os espectadores masculinos (ANDERSON, 1978).

O período romântico do século XIX revelava fascínio pelo sobrenatural, pelo exótico e pela fantasia. Nas imagens da dança, faziam-se presentes os contos de fadas e os romances melodramáticos e até pornográficos, que refletiam devaneios, angústias, ambiguidades psíquicas e sexuais. Os coreógrafos buscavam a magia, acentuando, sobretudo, os aspectos emocionais e intuitivos da natureza humana, em detrimento do aspecto racional. O romantismo exaltava a mulher, não tanto em sua condição de mãe, esposa ou amante, mas como uma representação do inacessível, do ideal sonhado pelo homem, que está disposto a sacrificar sua vida por isso (HANNA, 1999).

Personificando o caráter etéreo e sublime do cristianismo, Maria Taglioni (1804-1884) foi a primeira bailarina a subir à ponta dos pés. Isso ficou estabelecido como elemento essencial do balé, proeza 
reservada às mulheres, que predominavam em número no palco. Inúmeras bailarinas tentavam imitar Taglioni, começando assim uma tendência para a idealização e idolatria da figura feminina; apesar da ilusão de feminilidade, causada pelo corpete justo, saia até quase o tornozelo e somente pescoço e ombros desnudados, ser realçada e associada às visões sobrenaturais, nela prezava a ausência de qualquer vestígio de expressão carnal na forma de dançar, e por isso o estilo de Taglioni era considerado casto (ANDERSON, 1978).

Ao contrario de Taglioni, Fanny Elssler (1810-1884) dançava com grande calor humano, e era considerada impetuosa e pagã, tendo inclusive partilhado favores com homens abastados. Uma característica em sua dança é que ela se valia de disfarce masculino de forma surpreendente quando o enredo assim o requeria. Com isso, o espetáculo ganhou contornos eróticos, o culto da bailarina atingiu grandes proporções e muitos papéis masculinos passam a ser frequentemente dançados por bailarinas (HANNA, 1999; ANDERSON, 1978).

No final do século XIX e início do século XX surgiu Anna Pavlova (1881-1931), que combinou dois temperamentos estereotípicos de mulher, casta e libertina, sendo, como diziam na época, tanto Taglioni como Elssler, virgem e bacante. Todas essas bailarinas, em suas atuações, firmaram seu predomínio sobre o bailarino, e o papel deste se reduziu ao de porteur, que dava à bailarina uma aparência de pluma, enquanto a arrastava e exaltava de um lado para outro. Mesmo portadora de uma imagem de santa e virgem, a bailarina ainda sofria bastante preconceito, já contra o bailarino esse preconceito era mais sutil. Depois disso, os homens passaram a ser menos bem-vindos nos palcos e mais celebrados nos espaços esportivos (MELO; LACERDA, 2009).

Embora sob as luzes do palco as mulheres parecessem reinar absolutamente, na dança e na sociedade o domínio ainda era masculino: os homens tinham o poder como professores, coreógrafos, produtores e diretores, determinando praticamente todas as normas sobre cada papel. Segundo Hanna (1999), o balé clássico deixou um 
legado de imagens de papéis sexuais que, em relações heterossexuais e cavalheirescas, criaram essa ilusão romântica que legitima e encobre a dominação masculina, que seria combatida pelas bailarinas e coreógrafas do século XX.

Com a exaltação do feminino nos palcos, alguns homens foram eficazes em novas direções, tais como Sergei Diaghilev (1872-1929), do Ballets Russes, que deu vitalidade aos espetáculos, revivendo o balé e o ressurgimento dos homens na dança. $\mathrm{O}$ uso do espaço é um exemplo disso: no grand pas de deux, cada bailarino tem um pas solo, no qual o bailarino percorre o palco com saltos espetaculares e a bailarina executa passos muito menores e dentro de uma área mais restrita. Embutida na força de impulsão dos saltos do bailarino, está a acentuada representação de masculinidade, como observa Burt (1995). Também Michael Fokine (1880-1942) rompeu com a tradição da companhia coreografando movimentos similares para homens e mulheres; e George Balanchine (1904-1983) transformou seu legado quando escreveu balés de mulheres fortes e independentes, quase não necessitando apoio do homem.

Com Vaslav Nijinsky (1890-1950), dá-se o retorno do bailarino aos palcos e o consequente reconhecimento do bailarino. Nijinsky, que mantinha uma relação homossexual com Diaghilev, foi uma figura chave na reintrodução do balé masculino do século $\mathrm{XX}$, desenvolvendo representações de masculinidade que dominaram o balé e, até certo ponto, a dança moderna ao longo do século. Coreografando balés relacionados à sexualidade, gays e androginia, os papéis de Nijinsky, muitas vezes, lhe permitiram expressar "sensualidade e sensibilidade (convencionalmente feminina) com extraordinaria força e dinamismo (convencionalmente masculino)" (BURT, 1995, p. 84).

Deu-se, então, de forma lenta a alternância da importância dos papéis e imagens do masculino e do feminino nos palcos.

Até o século XIX, a maioria das mulheres artistas no campo dominado por homens obteve acesso à formação e ao conhecimento sob a proteção de um artista masculino, muitas vezes seu pai. Segundo 
Burt (1995), Bronislava Nijinska (1891-1972) foi a única coreógrafa mulher da primeira metade do século XX a trabalhar com os recursos de uma grande companhia de balé, o Ballets Russes. Mesmo tendo coreografado aproximadamente cinquenta balés e embora seu trabalho tenha se desenvolvido muito a partir dos avanços coreográficos iniciados por seu irmão, Nijinska custou a receber seu devido reconhecimento, sendo mais conhecida simplesmente como a irmã de Nijinsky. Abertamente feminista, ela encenou papéis masculinos, mostrando-se versátil e adaptável, questionando os papéis sociais rígidos destinados às mulheres. Somente nos últimos anos os historiadores de dança têm redescoberto as contribuições de Nijinsky e Nijinska para a dança e o uso do balé tradicional em novas formas expressivas, originando o balé moderno. Ao desnaturalizar e desestabilizar a representação de gênero na dança encenada no teatro, Nijinsky e Nijinska usavam estratégias desconstrutivas que são mais familiarmente associadas ao trabalho de coreógrafos/as pósmodernos/as (BURT, 1995).

A dança cênica ocidental do século XX desenvolveu-se, paradoxalmente, de forma contínua e inovadora. Em relação às ocupações, a dança era, e não deixa de ser, segregada e diferenciada no sexo, separando executantes, coreógrafos/as e diretores/ empresários, sendo estas últimas duas posições as mais "poderosas" e de dominação masculina (FOSTER, 1996). Já as mulheres teriam menos mobilidade ao longo desses segmentos, normalmente se dedicando, depois das apresentações, às funções do casamento e ensino em escolas. Nos bastidores e nos empreendimentos de renda mais alta, o domínio das decisões relacionadas ao ensino, coreografia e produção ficavam a cargo dos homens, havendo também distinção entre os heterossexuais e os gays. Estes últimos passaram a recorrer à carreira da dança, de menor prestígio e maior tolerância, para, no palco, criar "novas fantasias de si próprios e de suas relações interpessoais" (HANNA, 1999, p. 15).

Uma razão pela qual as mulheres inicialmente desenvolveram a dança moderna foi pelo acesso restrito às ocupações criativas e, porque, sem interesse em defender as tradições do balé, as pioneiras 
da dança moderna foram mais livres no desenvolvimento de formas novas e alternativas de representações, criando novos gêneros e dirigindo suas próprias companhias. A dança moderna proporcionou às mulheres a oportunidade de afirmar, como artista e mulher, sua independência face aos convencionalismos. Enquanto isso, os gays foram desencorajados a entrar em cena, pelo público que, ainda, considerava-os afeminados (BURT, 1995).

Segundo Banes (1998), entre as décadas de 20 e 60 do século passado, os movimentos de liberação das mulheres e dos gays surgiram com novos temas, e os/as coreógrafos/as, refletindo o seu tempo e desafiando seus antecessores com novas perspectivas e motivações, voltaram-se para a igualdade entre os sexos e a qualificação feminina, transgredindo a questão cultural das divisões sexuais. O início do moderno na dança se deu com mulheres educadas e de personalidade forte, ao mesmo tempo em que programas de dança eram criados em universidades. Isso ajudou a dança a se tornar uma carreira mais respeitável, pelo menos para as mulheres, pois para os homens ainda era discutível. Nesse período, muitos homens faziam carreira no cinema, com estilos ligados ao jazz e sapateado (HANNA, 1999).

Constrangidas financeiramente e descontentes com os papéis femininos de até então, as mulheres da dança moderna escolheram ser agentes, e não mais objetos. Com uma nova dimensão técnicoformal, simbólica e contextual em suas coreografias, passaram a ser admiradas pela plateia, aliviando antigos sentimentos de insignificância física e social impostos pelos homens. Esse novo estilo possibilitou às mulheres novas experimentações de corpo e vestimentas, que visavam liberdade física (HANNA, 1999).

As precursoras da dança moderna então fundaram suas próprias escolas, companhias, sendo também bailarinas, coreógrafas, empresárias, críticas e estudiosas, fazendo progressos e, de certa forma, elevando seu status na dança e na sociedade. Com essas características foi se compondo a primeira geração da dança moderna, com nomes como Isadora Duncan (1877-1927) e Ruth St. Denis (1879-1968). 
O estereótipo romântico da bailarina começou a se desfazer com Duncan e seu rompimento com o balé. Dizendo que o corpo deveria se expressar despojado de tudo o que o constrange, por ser o que há de mais nobre na arte, Duncan causou choque ao dançar com túnicas transparentes e pés descalços, o que era considerado tão ousado quanto a nudez. Ela fundou uma nova linguagem gestual que libertava o corpo dos convencionalismos da dança e da sociedade e sua expressão era uma reivindicação tanto do movimento feminista quanto desta dança que começava a surgir.

Já Ruth St. Denis intencionava provocar experiências místicas, insistindo no corpo feminino como um recipiente sensual para o espiritual. Representava também a natureza e aspectos espirituais do ser humano, muitas vezes usando de sua própria beleza e exotismo. Mesmo com uma presença de palco sensual, continuava sendo mística e seu objetivo era dar prazer, diversão e elevação, para que a plateia entrasse em contato com esse lado sublime da natureza e do mundo (GITELMAN, 1998; BANES, 1998). Juntamente com Ted Shawn (1891-1972), com quem foi casada, fundou a Denishawn School, inspirando a geração seguinte de coreógrafos/as da dança moderna.

Segundo Gitelman (1998), eles interpretavam muito bem os papéis de dama e cavalheiro, mas tendo uma relação pessoal conturbada, talvez pela bissexualidade de Shawn se separaram. Mais tarde, ele fundou sua própria companhia, Ted Shawn and His Men Dancers, toda masculina e com movimentações heroicas, atléticas e viris. Ele visava acabar com alguns tabus que impediam o desenvolvimento da dança masculina, e isso parece ter sido uma reação de defesa contra a sociedade, que tinha opiniões negativas sobre os homens que dançavam. Assim, Shawn conseguiu aumentar o status da dança masculina e contribuiu para devolver à dança sua força viril após o período de decadência do bailarino. Mas quando permitiu a entrada de bailarinas em sua companhia, inspirou-se na divisão puramente histórica das atividades femininas e masculinas, coreografando movimentos distintos para cada sexo, mantendo representações hegemônicas. Como exemplifica Garaudy (1980), o 
movimento dos homens seria grande no espaço, prolongando o corpo, como no caso dos guerreiros; já o das mulheres, seria fechado, no qual punhos e mãos exemplificariam atividades como o costurar ou ninar um bebê. Com exceção de Shawn poucos homens fizeram parte dessa primeira fase da dança moderna.

Já numa segunda geração, ainda na primeira metade do século XX, surge Martha Graham (1894-1991), figura de destaque na vanguarda. Dirigindo uma companhia só de mulheres até o final da década de 30, ela perseguiu as paixões femininas na história, na literatura e no mito. Preocupada com a luta da mulher pela dominação sem culpa, suas obras apresentavam temas com certas polaridades: paixão desenfreada e dever, atração e repulsa pelo amor, inibição e liberdade sexual, sem que as mulheres se reduzissem ao status de objetos sexuais. Na maioria de seus trabalhos, os papéis femininos retratavam mulheres de personalidade forte e dramas complexos, se dividindo entre uma herança puritana e a busca pela liberdade (HANNA, 1999; BURT, 1995).

Buscando exprimir o drama do mundo vivido, e muitas vezes, o drama das mulheres, Graham representou várias faces destas: esposa, amante, rainha, mãe, heroína. Seu uso coreográfico com elementos ginásticos, rijo esforço, resistência, bem como seus retratos de importantes personagens masculinos das mitologias hebraica e grega, e da história americana, atraiu os homens, embora o papel central fosse sempre dançado por uma mulher. Suas figuras masculinas subordinavam-se, invariavelmente, às figuras femininas, simbolizando, com frequência, pouco mais do que uma oposição fálica que atormenta ou seduz a heroína (ROUBAUD, 2001; HANNA, 1999; GARAUDY, 1980).

Da geração que já convive com o pós-moderno , José Limón (1908-1972) viu as mulheres como mandonas e maldosas, e coreografou para um elenco todo masculino, dando nobreza e força masculinas à suavidade dos movimentos. Preocupado também com questões sociais da época, vendo o/a artista como um porta-voz da consciência moral do período em que viviam, adotou um caminho de contestação, ora sutil, ora explícito, no qual buscava a construção de 
novas representações de masculinidade. Assim como Limón, Alvin Ailey (1931-1989) "negociava" com imagens mais conservadoras. $\mathrm{O}$ atletismo encontrado em algumas de suas obras foi encarado como um reforço de certos estereótipos masculinos positivos e heroicos (MELO; LACERDA, 2009).

Se as mulheres do inicio da dança moderna eram maioria, expressando uma nova proposta que teve relação com a postura feminina perante o mundo, no cenário que se segue, alguns bailarinos criaram coreografias que destacavam a si próprios, sem participação feminina nenhuma. Muitos coreógrafos importantes eram homens, apesar de continuarem as contribuições das precursoras da dança moderna (ANDERSON, 1978). Pode-se dizer que o período em que culminou o pós-modernismo foi também caracterizado pelas mudanças ocorridas no balé, que do clássico se fundiu com características da dança moderna, surgindo o que se chamou de balé moderno, neoclássico ou contemporâneo. Os bailarinos deste período atraíram a atenção da mídia e do público, revolucionando a dança masculina, num vocabulário de movimentos mais duros.

Dentre os responsáveis por expandir o papel masculino no balé contemporâneo está Rudolf Nureyev (1938-1993), que mesmo sendo homossexual, apresentava papéis que eram exemplos de bravura e atleticismo. Ao mesmo tempo, ele assumia papéis femininos e "fundindo agilidade animal com delicadeza humana, sua dança foi maior e mais sexual do que a de outros homens" (HANNA, 1999, p. 212).

Burt (1995) cita que uma das formas mais extremas de masculinidade numa narrativa é a luta, sendo que a sexualidade masculina é comumente associada com agressão e violência. Esse tema, segundo o autor, pode ser usado como pretexto para a apresentação de um espetáculo do corpo do bailarino, através de movimentos de exibição de combate que claramente usam qualidades de movimento convencionadas como masculinas e, portanto, sem problemas de identidade para o bailarino.

Inovador da dança, num estilo que não é nem clássico nem moderno, mas uma síntese e desenvolvimento das duas danças, 
Maurice Béjart (1927-2007) focava problemas sociais e filosóficos (GARAUDY, 1980). Segundo Hanna (1999) ele era favorável em lidar com temas homossexuais, mas preferiu a imagem masculina em muitas obras, com homens dançando mais vigorosamente em solos, duetos e conjuntos exclusivamente masculinos.

Contra a ideia de homens e mulheres como opostos, vistos mais como objeto sexual do que como pessoa, estava Alwin Nikolais (19101993), que com os próximos bailarinos pós-modernos "abstiveramse de estereótipos masculinos e femininos polarizados, em favor de movimentos unissex e bailarinos andróginos" (HANNA, 1999, p. 211), sendo então um dos primeiros a nivelar estas diferentes representações de masculinidade e feminilidade, buscando movimentações comuns a ambos os sexos.

Steve Paxton (1939) idealizou a Contact Improvisation, que induzia uma forma de execução que exigia total cooperação na entrega e na sustentação do peso corporal, independente do sexo do dançarino, eliminando noções de ativo e passivo, dominador e submisso. Em suas coreografias, ações cotidianas são exploradas, abolindo-se o virtuosismo, desencorajando qualquer exposição de uma masculinidade "positiva" no palco (MELO; LACERDA, 2009). A improvisação proporciona uma forma mais igualitária de representações de gênero, redefinindo possibilidades, oportunizando aos homens estar fisicamente perto de outros homens e mulheres, sem ser através de um sentido de confronto ou sexual. Essa prática desnaturaliza certas suposições sobre imagens de mulheres na dança, permitindo que elas façam movimentos fortes e arriscados, geralmente associados com a dança masculina.

Também visando a libertação dos corpos, quebrando normas que governam a dança, estão Yvonne Rainer (1934) e Senta Driver (1942). Valendo-se da androginia e invertendo as funções tradicionais de papéis sexuais, elas ofereceram uma recusa à diferenciação, com corpos de diferentes sexos, quase nus para serem considerados iguais, realizando movimentos idênticos com o mesmo esforço físico (BANES, 1998; GIL, 2004). 
Se afastando da ideia romântica da dança como uma carreira de emoções e sentimentos de herói, Merce Cunningham (1919-2009) buscou concretizar isso de forma diferente. Afirmando que qualidades estético-formais da dança eram mais importantes que a diferença entre os gêneros, que ele neutralizava no conteúdo e na expressividade de suas coreografias, e eliminando conotações de dominação e submissão, seu método de composição elimina qualquer visão romântica do papel masculino, da mesma forma que seus bailarinos/as raramente tentam parecer etéreos (ANDERSON, 1978).

Exemplificando uma abordagem diferenciada da de Merce Cunningham, a dança-teatro de Pina Bausch (1940-2009), revela preocupações com as questões de identidade e dominação masculina em características agressivas, brutais e controladoras do comportamento masculino. Bausch tinha obsessão quanto à opressão das mulheres, revelando no palco mal-humorados jogos de poder entre homens e mulheres, combinando além de violência entre os sexos, ternura com selvageria, celebração com desespero, erotismo ou excesso sexual. A separação entre os sexos e a relação de insatisfação e desejo se fazem presentes no trabalho da coreógrafa, principalmente em cenas em que entre um casal se dá a alternância de gestos carinhosos e agressões recíprocas, sinalizando a ausência e insaciável necessidade um do outro. Também há em sua companhia estereótipos do andar sexy das mulheres e dos gestos brutais e viris dos homens, mas também, homens tornando-se mulheres, em nítidas transformações de identidade de gênero (FERNANDES, 2007; HANNA, 1999; GIL, 2004).

Pode-se dizer que em cada linguagem artística a pósmodernidade assumiu um aspecto diferente e assim, uma pluralidade. Isso culminaria na diversidade da contemporaneidade, que abarca diferentes poéticas da dança, sendo que muitas não se enquadram nas classificações tradicionais, como balé e dança moderna (DANTAS, 2005).

Embora alguns coreógrafos/as levem ao palco mulheres como dominadas pelo homem, vítimas do amor, do destino e da violação 
física, tragédias clássicas de heróis foram recontadas com heroínas. Muitas danças também são coreografadas com bailarinas arrojadas, que se tocam e se sustentam umas às outras, e aos homens, como nunca o fizeram as bailarinas anteriores (HANNA, 1999). Dessa forma, obras recentes tendem a se afastar das imagens tradicionais, refletindo e transformando uma possível construção social das realidades contemporâneas, mostrando as mulheres como fortes e dominadoras, na busca pela quebra de antigos estereótipos.

Sob a classificação de dança contemporânea, abrigam-se modos distintos de expressão através de movimentos constituídos também por relações culturais, de forma que o corpo do/a bailarino/a, também, reflete os "contágios" culturais a que está submetido. Sintetizando elementos de construções estéticas anteriores, na contemporaneidade há a construção de novas linguagens, que mostram novos corpos, portadores de novos valores sociais e conteúdos simbólicos que se explicitam em coreografias que os articulam aos movimentos (SIQUEIRA, 2006).

Se houve um período em que a dança era moldada, tanto por técnicas quanto por condicionalismos históricos, sociais e culturais, há muitos corpos em movimento na contemporaneidade que recusam o adestramento técnico, buscando se apresentar como corpos comuns, nos quais há uma procura pela organicidade do movimento e uma intenção de desconstruir as concepções performativas convencionais (ROUBAUD, 2001).

Em relação às normas convencionais, há evidências que mostram certo incômodo com essa imagem do pertencimento da dança ao feminino. Vemos o surgimento de muitos trabalhos que tem interesse em abordar a questão da masculinidade na dança, e se pergunta se seria possível uma articulação tranquila entre masculinidade e dança. Parece que, dependendo do estilo, modos hegemônicos de viver o masculino tornam-se mais ou menos evidentes, tal como na constituição, mais ou menos, hegemônica da historia da dança. Ainda assim, muitos sofrem constrangimento por serem bailarinos, pois a associação da dança com a homossexualidade é latente, inibindo o início da prática entre meninos. 
$\mathrm{Na}$ contemporaneidade, composta por danças que se opõem às representações tradicionais entre os sexos, muitos coreógrafos contemporâneos criaram também coreografias em que criticavam a supremacia feminina no balé, nas quais bailarinos dançam nas pontas, travestidos de bailarinas de forma irônica, invertendo os valores clássicos desse estilo (SIQUEIRA, 2006). Assim, ideias codificadas de feminilidades e masculinidades inscritas em cada gênero/estilo são desmistificadas e paradoxos dos papéis sexuais se apresentam, expressando rupturas de certos padrões e modelos acerca desses papéis na dança, especialmente a dança cênica de tradição ocidental, de que se tratou aqui.

\section{Considerações finaIS}

Mais do que se aprofundar e comparar as questões estéticas de cada estilo de dança, este texto procurou mostrar como ao longo de sua história a dança revelou pessoas e momentos instigantes de se repensar no que se refere aos papéis sexuais.

Talvez uma das mais evidentes características da contemporaneidade seja o uso de movimentos cotidianos transformados para serem apresentados no palco. Da mesma maneira, realidades e estereótipos de papel sexual do cotidiano proporcionam material e contexto para compreensão da dança, apresentando ideias sobre corpo e gênero que nos levam a reflexões acerca das possibilidades da dança de continuar comunicando, expressando, revelando, manifestando, e por vezes, transformando, situações, construções e momentos da multiplicidade humana em suas relações, intenções e estereótipos.

Há corpos masculinos e femininos, que por si só proporcionam experiências diferentes, mas que não devem ser sempre diferentes. A sociedade, nesse sentido, muitas vezes é preconceituosa e intolerante em relação a certas atitudes, e um reflexo disso é a paralisação de muitos bailarinos talentosos, que se reprimem e limitam a dança masculina. Semelhantemente, bailarinas do período romântico sofreram com os domínios masculinos na dança e na 
sociedade, e associadas à prostituição, recorreram a outras profissões fora dos palcos da dança. Se auto afirmaram no período moderno, assim como os homens o fizeram com o atleticismo do pós-moderno. Ambos os sexos foram retratados de forma semelhante com a improvisação do pós-modernismo, eliminando-se conotações de dominação e submissão, e a alternância entre imagens de poder aos homens ou às mulheres passou a ser retratada com a chegada da contemporaneidade, que explicita a quebra de muitos estereótipos.

Dentre vários outros exemplos, pode-se perceber que na dança e em várias práticas sociais, os homens e as mulheres se relacionaram e se relacionam através de negociações, avanços, recuos, revoltas, alianças. Assim, as representações de gênero na dança, desde as origens do balé, se refletem na atual dança contemporânea de forma paradoxal, ao mesmo tempo com a manutenção e inovação, consentimentos e disputas, na luta pela desmistificação da essência da feminilidade, e por vezes, masculinidade, nos palcos e nos bastidores da dança. 
The female and male in dance: from the origins of the ballet to the contemporary stage

Abstract: The purpose of this work was to carry out a reflection on the female and male representations in the dance scenic of the western world, from the origins of the ballet to the contemporary stage. The main objective was to understand some moments of transition in relation to the sexual roles in contests and reciprocity, presented in the stage and sometimes out of it. The theoretical support of Cultural Studies in dance was utilized as a cultural practice in this study, including also as "texts" the bodies in motion; this provided a better understanding of coding styles of dance, which communicate, express and change the representations associated to female and male.

Key-words: Dance. Female and male representations. Cultural Studies.

La feminidad y masculinidad en la danza: de los orígenes del ballet a la contemporaneidad

Resumén: El objetivo de este estudio ha sido realizar un estudio de las representaciones de lo femenino y lo masculino en la danza escénica occidental, de los orígenes del ballet a la danza contemporánea. Se ha tratado de comprender algunos momentos de transición con respecto a los roles de cada género en los conflictos y reciprocidades presentados en el escenario y, en ocasiones, por fuera de este. El soporte teórico de los estudios culturales se utilizó en el estudio de la danza como una práctica cultural, incluyendo también como "textos" cuerpos en movimiento; esto permitió una mejor comprensión de la codificación de los estilos de danza, que se comunican, expresan y transforman las representaciones asociadas a lo femenino y a lo masculino.

Palabras-clave: Baile. Las representaciones de la feminidad y la masculinidad. Estudios Culturales. 


\section{REFERÊNCIAS}

ANDERSON, Jack. Dança. Tradução Maria da Costa. São Paulo: Verbo-Lisboa, 1978.

AU, Susan. Ballet and modern dance. London: Thames e Hudson, 2002.

BANES, Sally. Terpsichore in sneakers: post-modern dance. Boston: Houghton Mifflin, 1987.

BANES, Sally. Dancing women: female bodies on stage. London: Routledge, 1998.

BURT, Ramsay. The male dancer: bodies, spectacle, sexualities. London: Routledge, 1995.

CEVASCO, Maria Elisa. Dez lições sobre os estudos culturais. 2. ed. São Paulo: Boitempo, 2008.

DANTAS, Mônica. De que são feitos os dançarinos de "aquilo...": criação coreográfica e formação de intérpretes em dança contemporânea. Movimento, Porto Alegre, v. 11, n. 2, p. 31-57, maio/ago. 2005.

DESMOND, Jane C. Embodying Difference: issues in dance and cultural studies. In: DESMOND, Jane C. (Ed.). Meaning in Motion: new cultural studies of dance. Durham: Duke University Press, 1997.

ESCOSTEGUY, Ana Carolina. Estudos culturais: uma introdução. In: SILVA, Tomaz Tadeu. (Org.). O que é, afinal, estudos culturais? 3. ed. Belo Horizonte: Autêntica, 2004.

FERNANDES, Ciane. Pina Bausch e o Wuppertal Dança-Teatro: repetição e transformação. 2. ed. São Paulo: Annablume, 2007.

FOSTER, Susan Leigh. The ballerina's phallic pointe. In: FOSTER, Susan Leigh Foster (Ed.). Corporealities: dancing knowledge, culture and power. London: Routledge, 1996.

GARAUDY, Roger. Dançar a Vida. Tradução Glória Mariani e Antônio G. Filho. Rio de Janeiro: Nova Fronteira, 1980.

GIL, José. Movimento total: o corpo e a dança. São Paulo: lluminuras, 2004.

GITELMAN, Claudia. Dança moderna americana: um esboço. Pro-Posições, Campinas, v. 9, n. 2, p. 55-61, jun. 1998.

HANNA, Judith Lynne. Dança, sexo e gênero: signos de identidade, dominação, desafio e desejo. Tradução Mauro Gama. Rio de Janeiro: Rocco, 1999. 
HUSCHKA, Sabine. Moderner Tanz. Konzepte, Stile, Utopien. Reinbek bei Hamburg: Rowoht Taschenbuch, 2002.

JOHNSON, Richard. O que é, afinal, Estudos Culturais? In: SILVA, Tomaz Tadeu (Org.). O que é, afinal, estudos culturais? 3. ed. Belo Horizonte: Autêntica, 2004.

MCROBBIE, Angela. Dance Narratives and Fantasies of Achievement. In: DESMOND, Jane C. (Ed). Meaning in Motion: new cultural studies of dance. Durham: Duke University Press, 1997.

MELO, Victor Andrade; LACERDA, Claudio. Masculinidade, dança e esporte: "Jeux" (Nijinsky, 1913), "Skating Rink" (Borlin, 1922) e "Le Train Bleu" (Nijinska, 1924). Revista Brasileira de Ciências do Esporte, Campinas, v. 30, n. 3, p. 45-62, maio 2009.

PEREIRA, Roberto. Gruas vaidosas. In: PEREIRA, Roberto; SOTER, Silvia (Org.). Lições de Dança 1. 2. ed. Rio de Janeiro: Editora da UniverCidade, 2006.

ROUBAUD, Maria Luísa Galvez. Corpo e Imaginário: representações do corpo na dança independente de Portugal. Tese (Doutorado em Motricidade HumanaDança) - Faculdade de Motricidade Humana, Universidade Técnica de Lisboa, Lisboa, 2001.

SCHULMAN, Norma. O Centre for Contemporary Cultural Studies da Universidade de Birmingham: uma história intelectual. In:: SILVA, Tomaz Tadeu da. (Org.). 0 que é, afinal, estudos culturais? 3. ed. Belo Horizonte: Autêntica, 2004.

SIEGEL, Marcia. Visible Secrets: style analysis and dance literacy. In: MORRIS, Gay (Org.). Moving words: re-writing dance. London: Routledge, 1996.

SIQUEIRA, Denise da Costa Oliveira. Corpo, comunicação e cultura: a dança contemporânea em cena. Campinas: Autores Associados, 2006.

THOMAS, Helen. Do You Want to Join the Dance? - Postmodernism / Poststructuralism, the Body, and Dance. In: MORRIS, Gay (Org.). Moving words: re-writing dance. London: Routledge, 1996.

Endereço para correspondência:

Marília Del Ponte de Assis

Rua Votorantim, 101, apto 103/B. Vila Nova. CEP: 13.073-090. Campinas/SP.

Recebido em: 26.05.2012

Aprovado em: 16.01.2013 